\title{
Correction to: Multi-scale model of effects of roughness on the cohesive strength of self-assembled monolayers
}

\author{
Chen Zhang - Amnaya P. Awasthi · Jaeuk Sung • Philippe H. Geubelle $\mathbb{C}^{-}$ \\ Nancy R. Sottos
}

Published online: 28 February 2019

(C) Springer Nature B.V. 2019

Correction to: Int J Fract

https://doi.org/10.1007/s10704-017-0221-3

This article was published with an erroneous version of one of the author's names. Please find on this page the correct version of the author's names.
Publisher's Note Springer Nature remains neutral with regard to jurisdictional claims in published maps and institutional affiliations.

The online version of the original article can be found under https://doi.org/10.1007/s10704-017-0221-3.

C. Zhang · P. H. Geubelle ( $\square)$

Department of Aerospace Engineering, University of Illinois at Urbana-Champaign, Champaign, IL 61801, USA e-mail: geubelle@illinois.edu

A. P. Awasthi

Department of Mechanical and Aerospace Engineering, University of Florida, Gainesville, FL 32611, USA

J. Sung $\cdot$ N. R. Sottos

Department of Materials Science and Engineering, University of Illinois at Urbana-Champaign, Champaign, IL 61801, USA 